\title{
Documents Stéphane Mallarmé, Présentés par Gordon Millan
}

\section{Mario Richter}

\section{Q OpenEdition \\ 1 Journals}

\section{Edizione digitale}

URL: http://journals.openedition.org/studifrancesi/35011

DOI: 10.4000/studifrancesi.35011

ISSN: 2421-5856

\section{Editore}

Rosenberg \& Sellier

\section{Edizione cartacea}

Data di pubblicazione: 1 novembre 2005

Paginazione: 438

ISSN: 0039-2944

\section{Notizia bibliografica digitale}

Mario Richter, «Documents Stéphane Mallarmé, Présentés par Gordon Millan», Studi Francesi [Online], 146 (XLIX | II) | 2005, online dal 30 novembre 2015, consultato il 18 avril 2021. URL: http:// journals.openedition.org/studifrancesi/35011 ; DOI: https://doi.org/10.4000/studifrancesi.35011

Questo documento è stato generato automaticamente il 18 avril 2021.

\section{(c) (i) (9)}

Studi Francesi è distribuita con Licenza Creative Commons Attribuzione - Non commerciale - Non opere derivate 4.0 Internazionale. 


\title{
Documents Stéphane Mallarmé, Présentés par Gordon Millan
}

\author{
Mario Richter
}

\section{NOTIZIA}

Documents Stéphane Mallarmé, Nouvelle Série, III, Présentés par Gordon Millan, SaintGenauph, Librairie Nizet, 2003, pp. 214.

1 Questo terzo volume della serie Documents Mallarmé continua una già nota e meritoria impresa filologica, capace di offrire allo specialista e, in generale, ad ogni studioso un prezioso strumento di lavoro, col quale è possibile seguire nei minimi dettagli il processo di elaborazione dei testi mallarmeani dal momento della loro iniziale ideazione fino all'ultimo stadio a stampa passando attraverso tutti gli stadi intermedi.

2 In questo volume si trovano, illustrate appunto da note e accompagnate dalle varianti, la Préface à Vathek, il Volume sur le Divan, i Poèmes en prose e le Variations sur un sujet. 